\title{
Morphology and Properties of Agarwood-waste-filled Natural Rubber Latex Foam
}

Narissara Mahathaninwong, Thiensak Chucheep, Seppo Karrila, Wichuta Songmuang, Napat Rodsang, and Suphatchakorn Limhengha*

\begin{abstract}
Agarwood (Aquilaria crassna) (ACW) waste is widely available as a byproduct of agarwood essential oil production. In this study, ACW waste was ball milled into ACW powder (passed through 120 mesh) and used as filler in natural rubber latex foam (NRLF) prepared by the Dunlop method. The effects of the ACW filler on cell morphology and properties of the NRLF were determined. It was found that the ACW filler loading affected cell morphology of the NRLF. The cell size of the ACW-filled NRLF increased with ACW loadings of 1.5 parts per hundred parts of latex (phr) and $2.5 \mathrm{phr}$, compared with that of control NRLF. A bimodal cell size distribution (with large and small cells) was dominant in the ACW-filled NRLF at loadings of $3.5 \mathrm{phr}, 4.5 \mathrm{phr}, 5.5 \mathrm{phr}$, and $6.5 \mathrm{phr}$. The cell walls also became thicker, causing inferior compression set behavior. In addition, the density and hardness of the ACW-filled NRLF increased with ACW filler loading.
\end{abstract}

Keywords: Rubber foam; Agarwood waste; Aquilaria crassna; Natural rubber latex

Contact information: Faculty of Science and Industrial Technology, Prince of Songkla University (PSU) Surat Thani Campus, Surat Thani 84000, Thailand; *Corresponding author: suphatchakorn.l@ psu.ac.th

\section{INTRODUCTION}

Agarwood is resinous hardwood from trees of the genus Aquilaria. Most Aquilaria species are found in Southeast Asian countries (Siripatanadilox 2007), such as Malaysia, Thailand, Vietnam, and Indonesia. There are five Aquilaria species recorded in Thailand: A. subintegra, A. crassna, A. malaccensis, A. hirta, and A. rugosa (Eiadthong 2007). Aquilaria malaccensis is more widely traded than A. crassna in Thailand (Siripatanadilox 2007). However, farmers in eastern Thailand have mostly cultivated A. crassna, which, in Trat province, has support for distribution, seedling production, planting, and agarwood industry and business (Jamroenprucksa 2007). Agarwood (Aquilaria crassna) (ACW) is among the high-value fragrant woods from which essential oils are extracted. The desired compounds in this essential oil are neopetasane, dihydrokaranone, $\beta$-agarofuran, and agarospirol, which contribute to the fragrance (Thuy et al. 2019) and are used in perfumes. Additionally, agarwood essential oil has antimicrobial activity against Staphylococcus aureus and Candida albicans (Wetwitayaklung et al. 2009), pharmacological activity, and medical benefits (Dahham et al. 2016; Ahmed and Shafiul Islam 2020).

There are various ways to make ACW oil, such as water distillation, subcritical water extraction (Yoswathana et al. 2012), and supercritical fluid carbon dioxide extraction (Wetwitayaklung et al. 2009). The ACW oil industries in Trat and Chanthaburi provinces of Thailand use conventional aqueous distillation. The production of essential oil from agarwood starts with cutting the agarwood into chips. Subsequently, the chips are dried, milled, and fermented in water for approximately $5 \mathrm{~d}$ to $10 \mathrm{~d}$, followed by distillation for 5 d to 10 d (Jamroenprucksa 2007; Jindawech et al. 2015; Moungsrimuangdee et al. 2016). 
The extraction of ACW oil produces a lot of solid waste, which is used to make frankincense and incense products. Sauki et al. (2013) investigated utilizing the waste from distillation of ACW oil by converting it into a profitable oil well cement additive. Such reuse or recycling of waste reduces pollution and protects the environment. Moreover, products from ACW waste are interesting because of the fragrance. Aromatic products from natural rubber latex (NRL) filled with ACW waste were the focus of this study. The recent sharp decrease in demand for NRL (BOI 2018) has caused a decrease in the prices, and rubber farmers in Thailand have suffered from this.

Natural rubber latex comes from rubber trees (Hevea brasiliensis), which have been widely cultivated in southern and eastern Thailand (Kasikranan 2012). Natural rubber latex can be used as a raw material to directly produce some rubber products, such as gloves, condoms, balloons, catheters, baby soothers, dental dams, and foam rubber (Yip and Cacioli 2002). Adding value to ACW waste and to NRL would benefit the environment, rubber farmers, and Thailand overall.

Natural rubber latex in the form of NRL foam (NRLF) is used in porous rubber products, such as pillows, cushions, and mattresses. Bio-based fillers for NRLF have been investigated, including rice husk (Ramasamy et al. 2012, 2013a) and kenaf (Abdul Karim et al. 2016). The investigations found that rice husk powder filler increased the density, hardness, tensile strength, and filler-matrix interaction in NRLF. In contrast, the kenaf powder filler decreased tensile strength of NRLF. The kenaf-filled NRLF had irregular morphology, and the filler did not bind well with the matrix. These alternative fillers are low-cost, lightweight, less energy intensive, and environmentally friendly. However, ACW waste has not yet been tested as a candidate filler for NRLF, but the eventual development of fragrant products using ACW-filled NRLF is a good motivation. In addition, ACW waste has been tested as filler in a polymer composite membrane, and the mechanical properties of the membrane were improved by the ACW waste filler (Shahruddin and Jasni 2014). Therefore, this preliminary study examined the potential and the filler effects of ACW in NRLF. The morphology and properties of ACW-filled NRLF were investigated.

\section{EXPERIMENTAL}

\section{Materials}

Natural rubber latex

High ammonia latex concentrate (HA latex) NRL was obtained from Chalong Latex Industry Co., Ltd. (Songkhla, Thailand). It had 60\% dry rubber content (DRC), $61.5 \%$ total solids content (TSC), and $0.7 \%$ ammonia by weight. Sulfur, potassium oleate, poly(dicyclopentadiene-co- $p$-cresol) (Lowinox CPL), zinc diethyldithiocarbamate (ZDEC), zinc 2-mercaptobenzhiozole (ZMBT), zinc oxide ( $\mathrm{ZnO})$, diphenyl guanidine (DPG), and sodium silicofluoride (SSF) used in this study were supplied by Sunny World Chemicals Co., Ltd. (Bangkok, Thailand).

\section{ACW waste}

The ACW waste was received from the Agro-Production Community Enterprise Community of Trat Province, Thailand. The ACW waste was a by-product from ACW oil extraction by aqueous distillation. The chemical composition of the as-received ACW waste was examined by X-ray fluorescence spectrometry (XRF, PW2400, Philips, Amsterdam, The Netherlands) 
A $10 \%$ ACW filler dispersion was then prepared by adding bentonite $(5 \mathrm{~g})$, vultamol $(5 \mathrm{~g})$, and distilled water $(440 \mathrm{~mL})$ into $50 \mathrm{~g}$ of as-received ACW waste. Subsequently, the mixture was ball milled for $72 \mathrm{~h}$ and sieved through 120 mesh.

\section{Foam Sample Preparation}

The formulation and materials used in this study are shown in Table 1. First, the HA-type NRL was filtered, measured, and stirred using a mechanical stirrer for approximately $30 \mathrm{~min}$. Next, potassium oleate soap, vulcanizing agent (sulfur), and ZMBT together with ZDEC and antioxidant (CPL) were added and stirred at $120 \mathrm{rpm}, 240 \mathrm{rpm}$, $360 \mathrm{rpm}$, and $120 \mathrm{rpm}$ for approximately $1.5 \mathrm{~min}, 1.5 \mathrm{~min}, 1.5 \mathrm{~min}$, and $1.5 \mathrm{~min}$, respectively. Then, the $10 \%$ dispersion of ACW waste powder was added and stirred at $120 \mathrm{rpm}$ for approximately $2 \mathrm{~min}$.

Next, DPG, together with zinc oxide $(\mathrm{ZnO})$, was added as the primary gelling agent to the foam, and beating was continued for another $90 \mathrm{~s}$ by stirring at $240 \mathrm{rpm}$. Immediately after, SSF (the secondary gelling agent) was added, and the foam was beaten for another $30 \mathrm{~s}$ by stirring at $240 \mathrm{rpm}$.

Finally, the un-gelled foam was quickly poured into an aluminum mold and allowed to gel for $7 \mathrm{~min}$ at ambient temperature. The gelled foam was then vulcanized by steam at $100{ }^{\circ} \mathrm{C}$ for $1 \mathrm{~h}$. Once the foam was cured, it was stripped from the mold and washed thoroughly with de-ionized water to remove potassium oleate soap and excess unreacted chemicals.

After washing, the cured NRLF was dried in a hot-air oven at $70{ }^{\circ} \mathrm{C}$ for $5 \mathrm{~h}$. The well-dried foam was off-white. The same procedure was used to produce the control sample of NRLF without ACW waste powder filler.

The following steps were the same as in the preparation of the NRLF control sample without ACW waste powder loading. The proportions (in parts per hundred parts of latex (phr)) of all the chemicals are shown in Table 1.

Table 1. Formulation of NRLF Filled with ACW Powder

\begin{tabular}{|c|c|c|}
\hline Ingredient & Total Solids Content (\%) & Formulation (phr) $^{1}$ \\
\hline NRL (HA latex) $)^{2}$ & 60 & 100 \\
\hline Sulfur & 50 & 2.5 \\
\hline Zinc oxide & 50 & 5 \\
\hline Lowinox $\mathrm{CPL}^{3}$ & 50 & 1 \\
\hline ZDEC $^{4}$ & 50 & 1 \\
\hline $\mathrm{ZMBT}^{5}$ & 50 & 1 \\
\hline $\mathrm{DPG}^{6}$ & 33 & 0.83 \\
\hline SSF $^{7}$ & 20 & 0.12 \\
\hline Potassium oleate & 10 & 0.5 \\
\hline $\mathrm{ACW}^{8}$ & 10 & $0,1.5,2.5,3.5,4.5,5.5,6.5$ \\
\hline
\end{tabular}

${ }^{1}$ Amounts are given as parts per hundred parts of latex (phr).

${ }^{2}$ Natural rubber latex

${ }^{3}$ Poly(dicyclopentadiene-co-p-cresol)

${ }^{4}$ Zinc diethyldithiocarbamate

${ }^{5}$ Zinc 2-mercaptobenzhiozole

${ }^{6}$ Diphenylguanidine

7 Sodium silicofluoride

${ }^{8}$ Agarwood (Aquilaria crassna) (ACW) waste

The other latex chemicals (i.e., Lowinox CPL, ZMBT, ZDEC, DPG, and SSF were manufactured by Zarm Scientific and Supplies Sdn. Bhd., Malaysia. 


\section{Visual Inspection of Foaming and Gelling Stages}

Bubble formation was inspected visually, and the gel time for each experimental condition was measured. Macroscopic foam surfaces after vulcanization were photographed with a cell phone camera using $4 \times$ magnification.

\section{Morphology Characterizations of ACW-filled NRLF Samples}

Scanning electron microscopy (SEM) was used to study the surface morphology of the ACW-powder-filled NRLF samples. First, the ACW-powder-filled NRLF samples were sputter-coated with a thin layer of gold to avoid electrostatic charging during imaging. Then, the coated foam samples were mounted on aluminum stubs. From the SEM micrographs, the rubber-filler interactions, the ACW dispersion, and the pore morphology of the foams were assessed.

\section{Properties of ACW-filled NRLF Samples}

The densities of the ACW-filled NRLF samples were measured by the displacement method in accordance with ASTM D1056 (2014).

The hardness of an ACW-filled NRLF sample was measured using a Shore durometer (LX-AO) (DUNDOO, LX Series Analog Shore Durometer, China). Five points for each ACW loading were measured, and the average results were reported.

In the compression set test, the ACW-filled NRLF samples were compressed to $50 \%$ of their original thickness $\left(t_{0}\right)$ at $70{ }^{\circ} \mathrm{C} \pm 1{ }^{\circ} \mathrm{C}$ for $22 \mathrm{~h}\left(t_{\mathrm{s}}\right.$ is the thickness at $\left.50 \%\right)$. Next, the compression was released, and the test sample was allowed to rest for $30 \mathrm{~min}$ at room temperature before the final thickness $\left(t_{\mathrm{f}}\right)$ was measured. The compression set percentage $\left(C_{\mathrm{d}}\right)$ was determined as follows $($ Eq. 1):

$$
C_{\mathrm{d}}=\left(t_{0}-t_{\mathrm{f}}\right) /\left(t_{0}-t_{\mathrm{s}}\right) \times 100 \%
$$

\section{Swelling of ACW-filled NRLF Samples}

Swelling testing was used to assess rubber-filler interactions as in a prior study (Muniandy et al. 2012). The ACW-filled NRLF samples with dimensions of $30 \mathrm{~mm} \times 5$ $\mathrm{mm} \times 2 \mathrm{~mm}$ were accurately weighed, immersed in toluene, and allowed to swell in a closed bottle for $72 \mathrm{~h}$ at room temperature $\left(25^{\circ} \mathrm{C}\right)$. When the sample was removed, its surface was quickly wiped dry, and the sample was weighed. It was then dried in an oven at $70{ }^{\circ} \mathrm{C}$ for $15 \mathrm{~min}$ and weighed again. The weight of toluene uptake per gram of rubber hydrocarbon $(Q)$, was determined according to Eq. 2.

$$
\mathrm{Q}=\frac{\text { Swollen weight }- \text { Dried weight }}{\text { Original weight } \mathrm{x}(100 / \text { Formula weight })}
$$

The rubber-filler interactions were estimated using the Lorenz and Park equation (Eq. 3):

$$
\frac{\mathrm{Q} f}{\mathrm{Q} g}=\mathrm{ae}^{-\mathrm{z}}+\mathrm{b}
$$

where the subscripts $f$ and $g$ refer to filled and gum vulcanizates, respectively, $Z$ is the ratio of filler to rubber by weight in the vulcanizate, and $a$ and $b$ are constants. 


\section{RESULTS AND DISCUSSION}

\section{Visual Inspection of Foaming and Gelling Stages}

Visual inspections in the foaming and gelling stages of the NRLF without ACW filling ( $0 \mathrm{phr}$, or control NRLF) and with ACW filling (ACW loadings of $1.5 \mathrm{phr}, 2.5 \mathrm{phr}$, $3.5 \mathrm{phr}, 4.5 \mathrm{phr}, 5.5 \mathrm{phr}$, and $6.5 \mathrm{phr}$ ) are shown in Table 2. The control NRLF had fine bubbles of uniform size and a specular surface after vulcanization, and the cases with 1.5 phr ACW and $2.5 \mathrm{phr}$ ACW in NRLF were similar in these respects. However, gel time increased with ACW loading, and the number density of the foam cells increased while they decreased in size, relative to the unfilled control NRLF. Classical nucleation theory of polymer foams proposes two types of cases, homogenous and heterogeneous, and the addition of solid particles to a solution leads to heterogeneous nucleation (Mokhtari Motameni Shirvan et al. 2016). The homogenous bubble nucleation site in control NRLF was potassium oleate, whereas the filled NRLF had both potassium oleate and ACW particles as homogenous and heterogeneous bubble nucleation sites, respectively. The small loading levels of $1.5 \mathrm{phr}$ and $2.5 \mathrm{phr}$ did not yet cause much heterogeneous nucleation, therefore maintaining fine and uniform bubbles. However, the greater ACW filler loadings of $3.5 \mathrm{phr}$ to $6.5 \mathrm{phr}$ yielded non-uniform bubbles in the foaming stage and long gel times, which may be caused by the heterogeneous nucleation occurring simultaneously with homogenous nucleation. The surfaces after vulcanization showed enlarged pores.

\section{Morphology Characterizations of ACW-filled NRLF Samples}

Figures 1(a) and 1(b) present micrographs of the control NRLF, clearly revealing open and closed cell morphologies. The micrographs of the ACW-filled NRLF at the low loading of $1.5 \mathrm{phr}$ ACW are shown in Fig. 1(c) and 1(d), in which polyhedral and semiclosed cells are apparent. The cell sizes in the $1.5 \mathrm{phr}$ ACW-filled NRLF were heterogeneous and larger than those of the control NRLF.

The cells in the $2.5 \mathrm{phr}$ ACW-filled NRLF were larger than those with the $1.5 \mathrm{phr}$ ACW filler or in the control NRLF, and they were mostly open, as shown in Figs. 1(e) and 1(f). Thick cell walls started to form in the foams with ACW loadings of $3.5 \mathrm{phr}$ or greater, as shown in Figs. 2(a) and 2(b). A bimodal cell size distribution was seen in these foams. Cell walls in the $3.5 \mathrm{phr}$ ACW-filled NRLF were thicker than those in the $1.5 \mathrm{phr}$ and 2.5 phr ACW-filled NRLF or the control NRLF. Cell wall thickness in the ACW-filled NRLF increased with ACW loadings of $4.5 \mathrm{phr}, 5.5 \mathrm{phr}$, and $6.5 \mathrm{phr}$, and there was a bimodal cell size distribution, as shown in Figs. 2(c) to 2(h). Various factors influence the cell morphology of foams, such as temperature, pressure, type of polymeric material, the formulation used (Ariff et al. 2008), filler type (Cao et al. 2005), and amount of filler (Tangboriboon et al. 2015). A nanoparticle filler yielded heterogeneous nucleation sites during cell formation, which reduced the cell size compared to a foam without the filler (Cao et al. 2005). Vahidifar et al. (2016) stated that increasing viscosity and curing density inhibits bubble growth, leading to reduced cell size. That result is different from this current work, in which the cell size increased as ACW filler loading increased. The cell size increase with any parameter helps gas release during the foaming process (Vahidifar $\mathrm{et} \mathrm{al}$. 2016). In this work, the obtained micrographs clearly suggested that the amount of ACW filler was an important factor affecting cell morphology, as in the prior study of Tangboriboon et al. (2015). 
Table 2. Foaming and Gelling Inspections

\begin{tabular}{|c|c|c|c|}
\hline $\begin{array}{l}\text { ACW Filler Loading in } \\
\text { the Foam (phr) }\end{array}$ & $\begin{array}{c}\text { Foam } \\
\text { Characteristics } \\
\end{array}$ & $\begin{array}{l}\text { Gel Time } \\
(\mathrm{min})\end{array}$ & Foam Surface after Vulcanization \\
\hline 0 & $\begin{array}{l}\text { Fine and uniform } \\
\text { bubbles }\end{array}$ & 1 & \\
\hline 1.5 & $\begin{array}{l}\text { Fine and uniform } \\
\text { bubbles }\end{array}$ & 2 & \\
\hline 2.5 & $\begin{array}{l}\text { Fine and uniform } \\
\text { bubbles }\end{array}$ & 3 & \\
\hline 3.5 & $\begin{array}{l}\text { Non-uniform } \\
\text { bubbles }\end{array}$ & 5 & \\
\hline 4.5 & $\begin{array}{l}\text { Non-uniform } \\
\text { bubbles }\end{array}$ & 5 & \\
\hline 5.5 & $\begin{array}{l}\text { Non-uniform } \\
\text { bubbles }\end{array}$ & 6 & \\
\hline 6.5 & $\begin{array}{l}\text { Non-uniform } \\
\text { bubbles }\end{array}$ & 7 & \\
\hline
\end{tabular}




\section{bioresources.com}

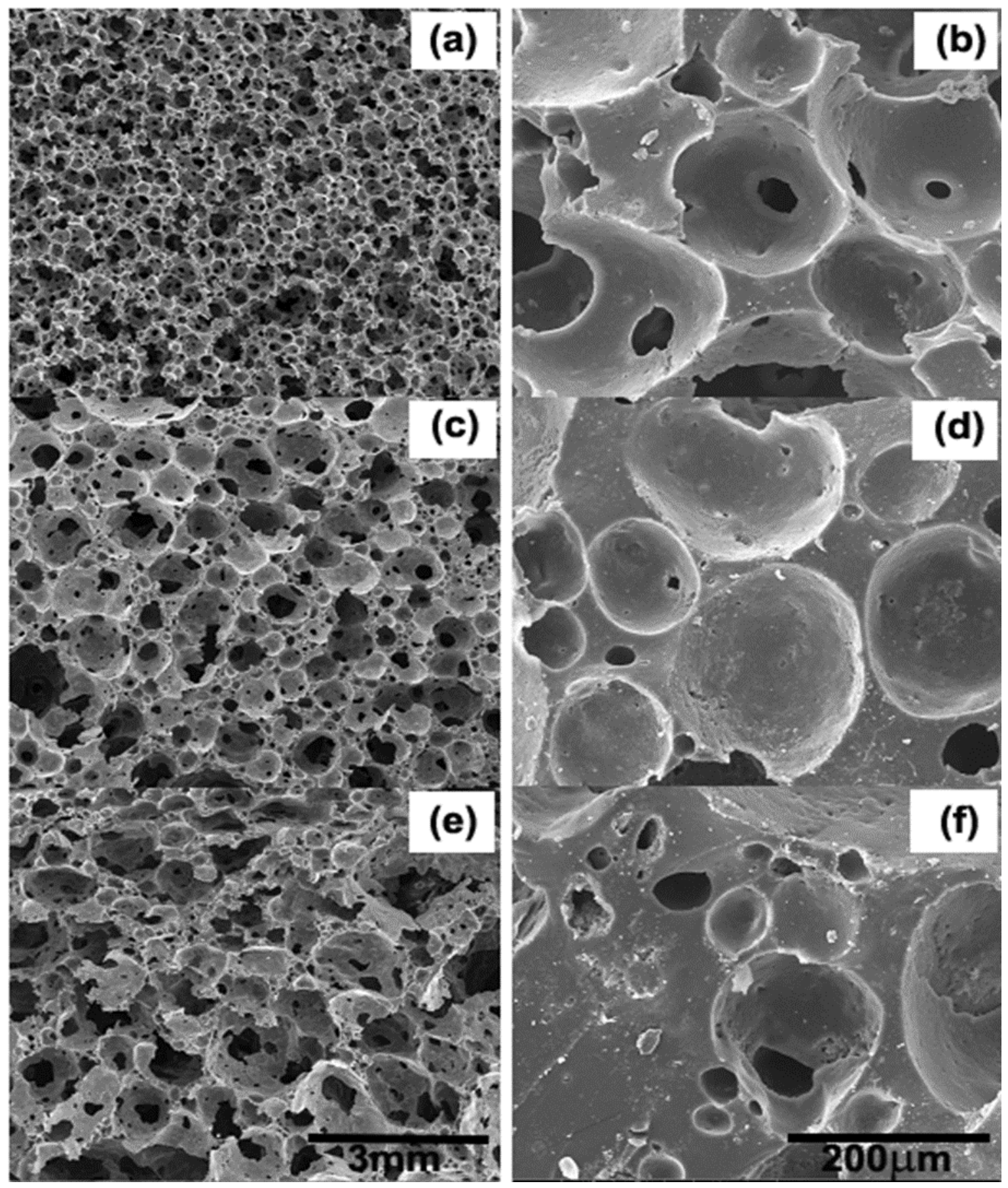

Fig. 1. Cell morphologies of NRLF samples: control at (a) $15 x$ and (b) $250 \times$, ACW filler loading of $1.5 \mathrm{phr}$ at (c) $15 \times$ and (d) $250 \times$, and ACW filler loading of $2.5 \mathrm{phr}$ at (e) $15 \times$ and (f) $250 \times$ 


\section{bioresources.com}

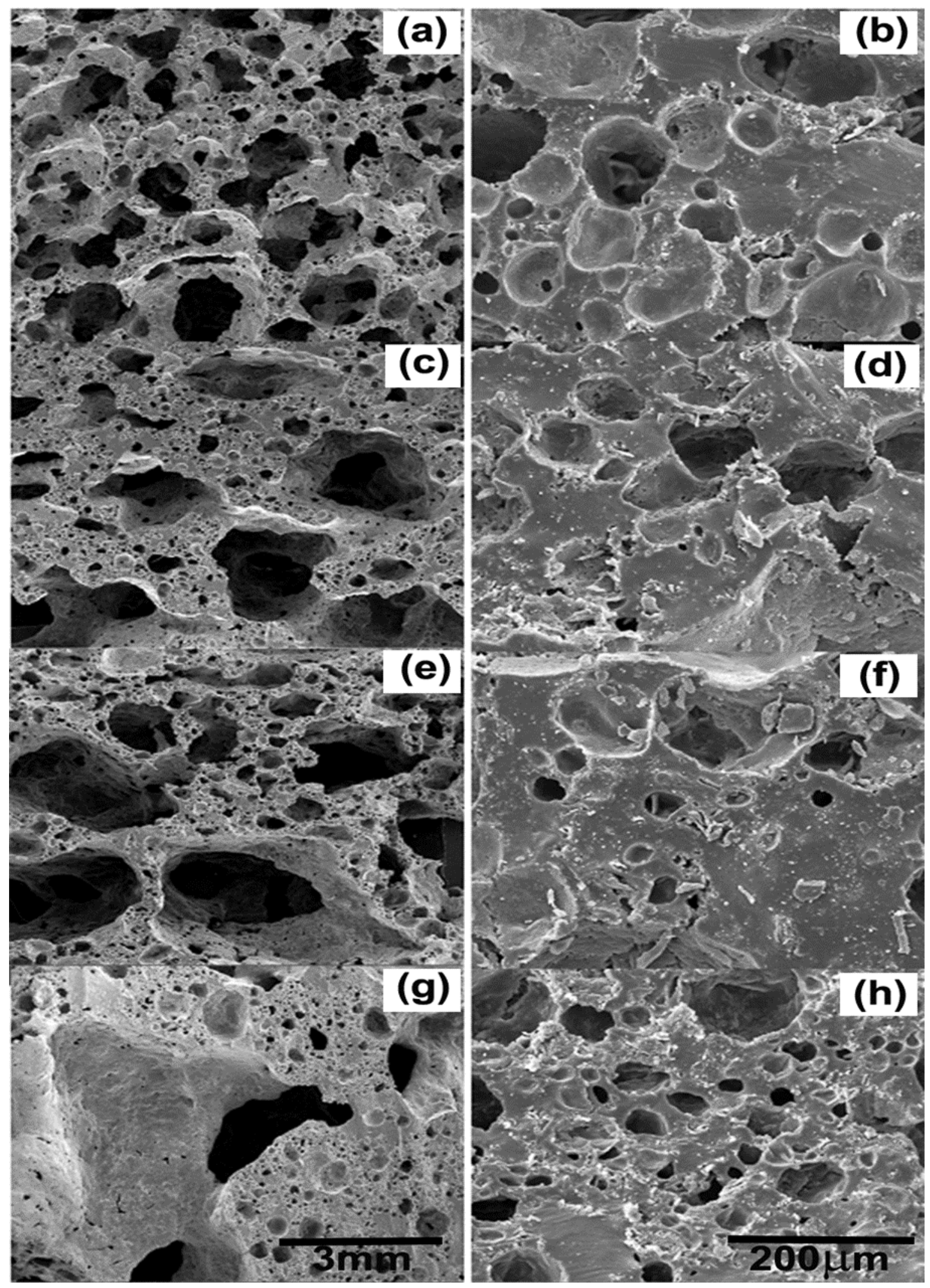

Fig. 2. Cell morphologies of NRLF samples with ACW filler loadings of $3.5 \mathrm{phr}$ at (a) $15 \times$ and (b) $250 \times, 4.5 \mathrm{phr}$ at (c) $15 \times$ and (d) $250 \times, 5.5 \mathrm{phr}$ at (e) $15 x$ and (f) $250 \times$, and 6.5 phr at (g) $15 x$ and (h) $250 \times$ 


\section{Density of ACW-filled NRLF Samples}

Figure 3 presents the effects of ACW filler loading on the density of filled NRLF. The density of the control NRLF (without ACW filler) was $161.6 \mathrm{~kg} / \mathrm{m}^{3}$. The densities of the NRLF with ACW filling in the range of $1.5 \mathrm{phr}$ to $3.5 \mathrm{phr}$ were lower than the control NRLF. The densities of the $1.5 \mathrm{phr}, 2.5 \mathrm{phr}$, and $3.5 \mathrm{phr}$ ACW-filled NRLF were $143.4 \mathrm{~kg} / \mathrm{m}^{3}, 153.3 \mathrm{~kg} / \mathrm{m}^{3}$, and $161.1 \mathrm{~kg} / \mathrm{m}^{3}$, respectively. Typically, NRLF with filler would have a greater density than that without filler (Najib et al. 2009), in contrast to these results.

Upon increasing the amount of ACW filler to $4.5 \mathrm{phr}, 5.5 \mathrm{phr}$, and $6.5 \mathrm{phr}$, the density of the ACW-filled NRLF exceeded that of the control NRLF. Additionally, the density of the ACW-filled NRLF increased steadily with filler loading.

The chemical crosslinking strongly affects foam density, as it can generate a network of tightly packed polymer chains (Ariff et al. 2008; Najib et al. 2009). Thinner cell walls can indicate a lower crosslinking density (Najib et al. 2009). It is possible that increasing the loading of ACW filler contributed to chemical crosslinking and thereby increased the cell wall thickness (as shown in Fig. 2(c) to 2(h)) and the density of the ACWfilled NRLF.

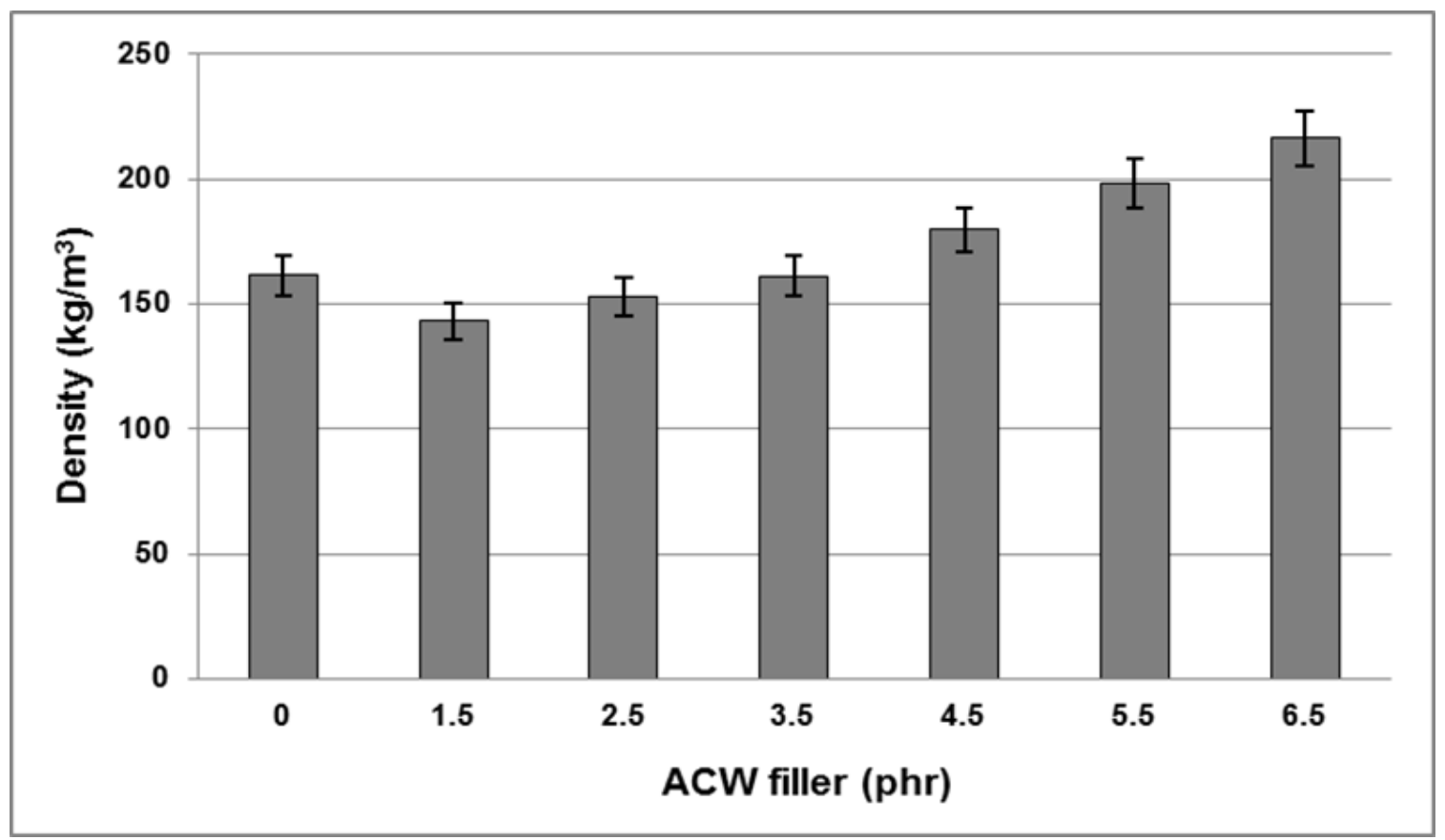

Fig. 3. Density of ACW-filled NRLF at various ACW filler loadings

\section{Hardness of ACW-filled NRLF Samples}

Figure 4 presents the effects of ACW filler loading on the hardness of the NRLF. The control NRLF had the lowest hardness, below the limit of Shore scale A. The hardness of ACW-filled NRLF increased with increasing filler loading. This result indicates that ACW filler contributes to harder NRLF, which is consistent with effects of rice husk and kenaf fillers (Ramasamy et al. 2013a,b; Kudori et al. 2019). 


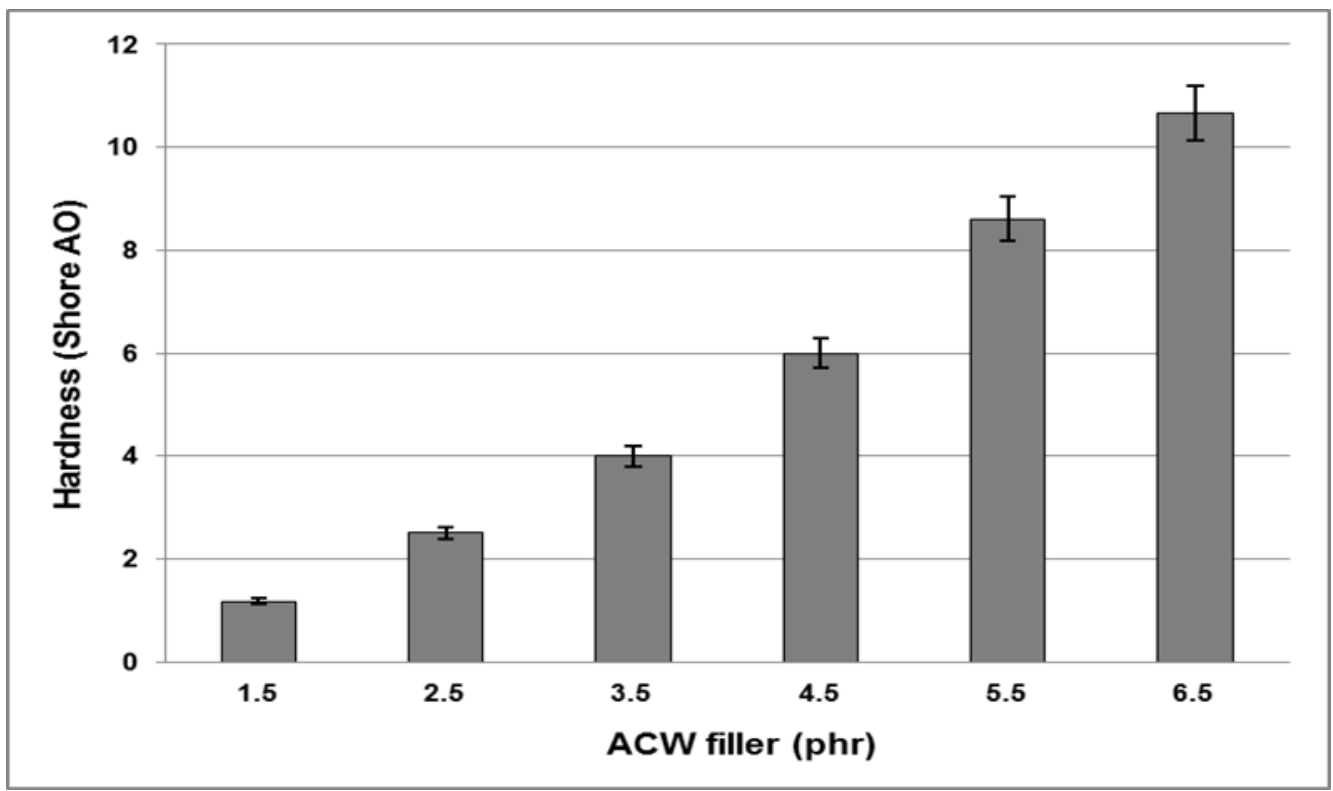

Fig. 4. Hardness of ACW-filled NRLF at various ACW filler loadings

\section{Compression Set of ACW-filled NRLF Samples}

The dimensional durability and stability of ACW-filled NRLF under stress was determined in terms of the compression set. Figure 5 shows that the compression set of the ACW-filled NRLF increased with increased filler loading. High ACW filler loadings of $4.5 \mathrm{phr}, 5.5 \mathrm{phr}$, and $6.5 \mathrm{phr}$ yielded high compression sets ( $\geq 20 \%)$, while the compression set was $10.5 \%$ for both the $2.5 \mathrm{phr}$ and $3.5 \mathrm{phr}$ ACW-filled NRLF samples. The lowest ACW loading of $1.5 \mathrm{phr}$ yielded a compression set of $9.5 \%$, which was the least among the filled NRLF. However, the control NRLF had an even lower compression set (8.4\%), less than any of the ACW-filled NRLF samples.

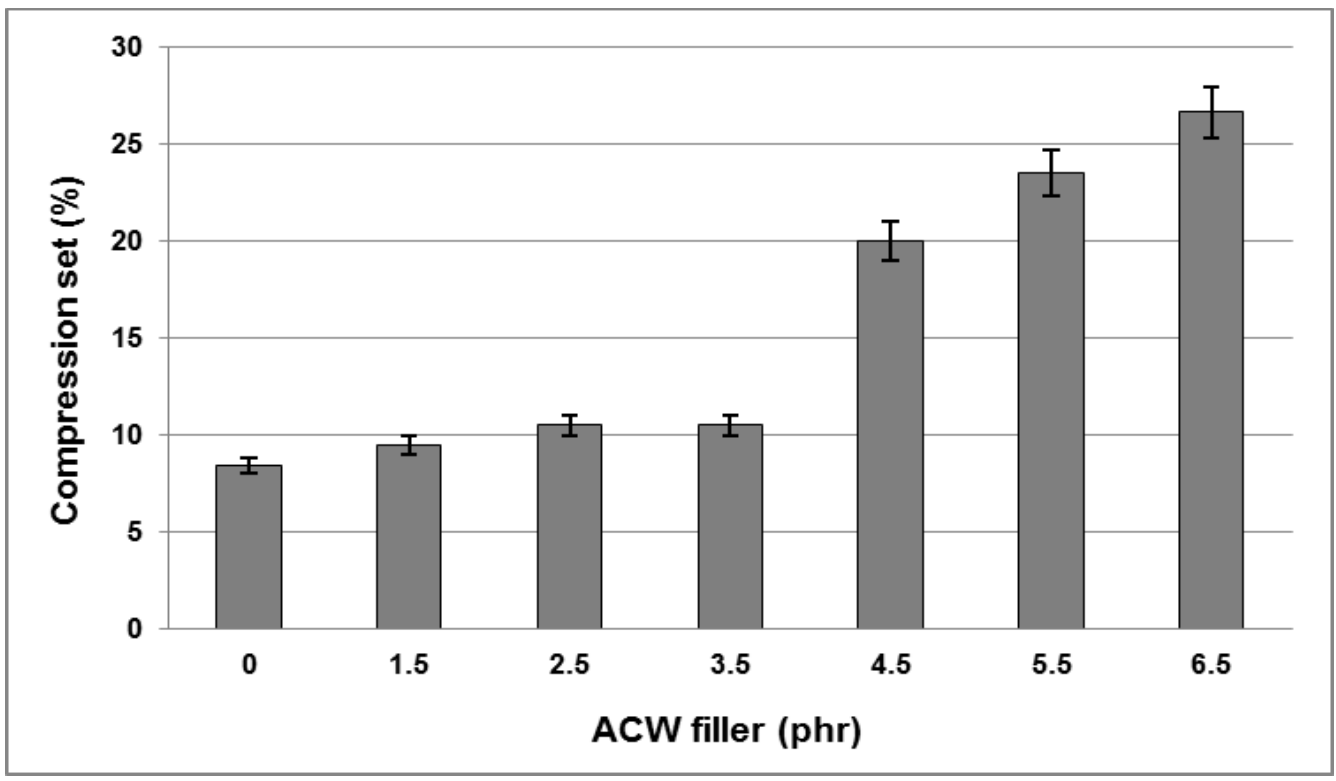

Fig. 5. Compression set values of control NRLF (without filler) and NRLF with various ACW filler loadings 
Both cell wall thickness and cell size of the foam affect the compression set. Zakaria et al. (2007) suggested that a foam with thinner cell walls and larger cell sizes has a more elastic behavior and better compression set behavior than that with thicker cell walls and larger cell sizes. In this work, the control NRLF with comparatively thin cell walls and small cell sizes had good compression set behavior. The compression set behavior of the $1.5 \mathrm{phr}, 2.5 \mathrm{phr}$, and $3.5 \mathrm{phr}$ ACW-filled NRLF was slightly inferior, with thicker cell walls and larger cell sizes, as shown in Figs. 1 and 2. The cases with $4.5 \mathrm{phr}, 5.5 \mathrm{phr}$, and $6.5 \mathrm{phr}$ ACW filler loadings had bimodal cell size distributions and thicker cell walls, as shown in Fig. 2, leading to clearly inferior compression set behavior. Nevertheless, the compression sets of the $1.5 \mathrm{phr}, 2.5 \mathrm{phr}, 3.5 \mathrm{phr}$, and $4.5 \mathrm{phr}$ ACW-filled NRLF are acceptable according to Thai industrial product standards (TIS 173-2519), for NRLF (Industrial product standards Act, 1976), in which the compression set must not exceed $20 \%$. Such acceptable loadings could be used to make fragrant foam rubber products, including mattresses and pillows.

\section{Swelling of ACW-filled NRLF Samples}

Figure 6 displays the trend of rubber-filler interactions $(Q f / Q g)$ in the ACW-filled NRLF samples. A lower $Q f / Q g$ indicates stronger filler-matrix interactions (Ismail et al. 1999). The results showed that ACW filler decreased the $Q f / Q g$ ratio, which consistently decreased with the filler loading. This result explains why the ACW filler provided good rubber-filler interactions in the ACW-filled NRLF. A similar study with rattan powder as the filler in natural rubber compounds has been reported (Muniandy et al. 2012). Increasing the amount of ACW filler reduced filler-filler interactions but increased filler-matrix interactions. This increased crosslink formation. These results are further supported by morphological evidence (Ramasamy et al. 2012).

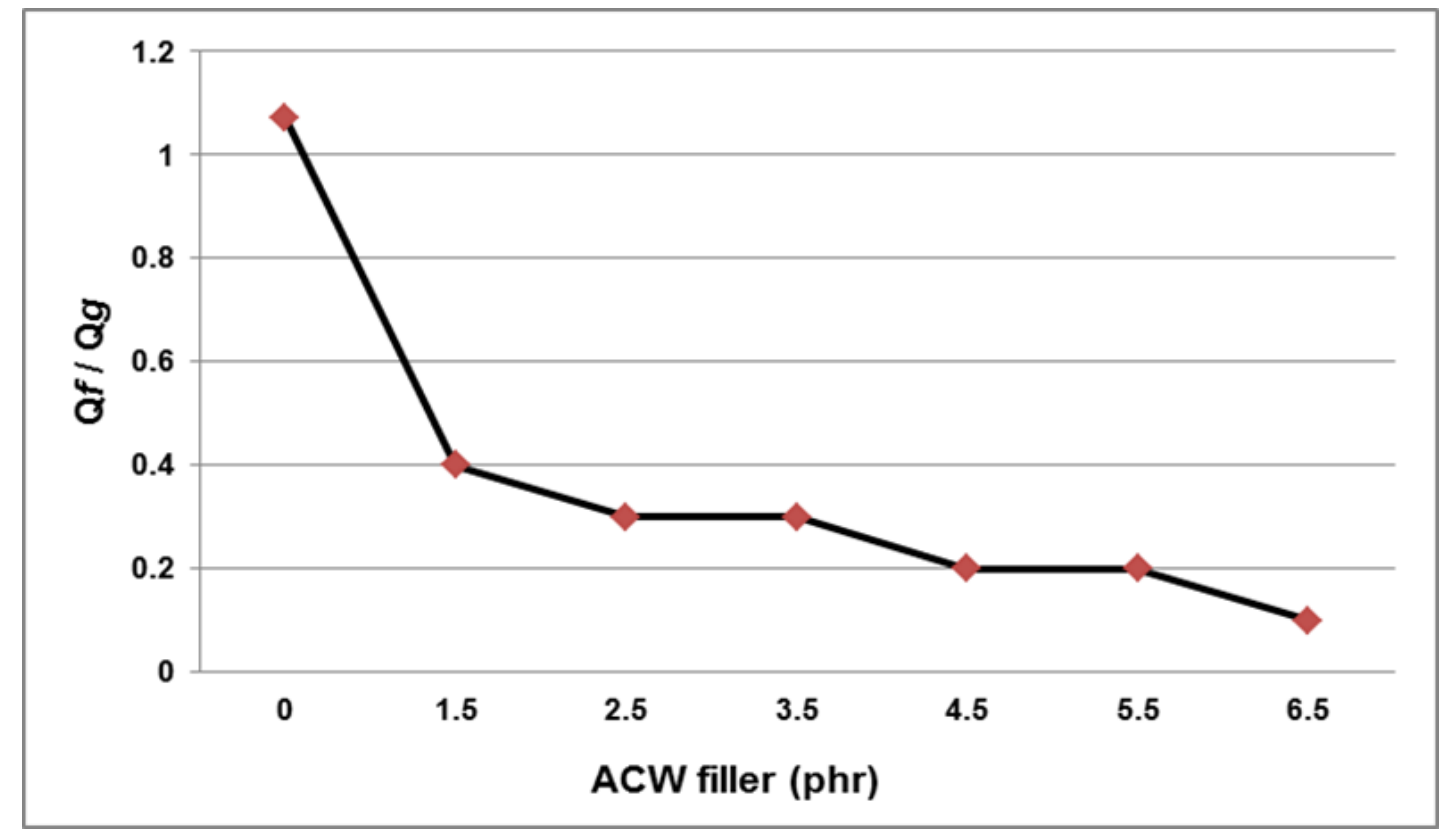

Fig. 6. Rubber-filler interactions in the NRLF at various ACW filler loadings 


\section{CONCLUSIONS}

1. Increasing the loading of fragrant ACW filler in NRLF from $1.5 \mathrm{phr}$ to $6.5 \mathrm{phr}$ affected the cell morphology of the foam. The cell size in ACW-filled NRLF increased with filler loadings of $1.5 \mathrm{phr}$ and $2.5 \mathrm{phr}$, compared with that of the control NRLF without filler.

2. A bimodal cell size distribution, with large and small cells in the ACW-filled NRLF, was mainly formed at greater $(3.5 \mathrm{phr}, 4.5 \mathrm{phr}, 5.5 \mathrm{phr}$, and $6.5 \mathrm{phr})$ loading levels. The cell walls also became thicker. In addition, the density and hardness of the ACW-filled NRLF increased with filler loading.

3. The compression set of the ACW-filled NRLF samples was poor at the $5.5 \mathrm{phr}$ and 6.5 phr loadings, exceeding $20 \%$. However, the compression set with the $1.5 \mathrm{phr}, 2.5 \mathrm{phr}$, $3.5 \mathrm{phr}$, and $4.5 \mathrm{phr}$ loadings was acceptable according to the Thai industrial product standard (TIS 173-2519) for NRLF (Industrial product standards Act, 1976).

\section{ACKNOWLEDGMENTS} Campus.

This research was partially supported by Prince of Songkla University, Surat Thani

\section{REFERENCES CITED}

Abdul Karim, A. F., Ismail, H., and Ariff, Z. M. (2016). "Properties and characterization of kenaf-filled natural rubber latex foam," BioResources 11(1), 1080-1091. DOI: 10.15376/biores.11.1.1080-1091

Ahmed, S., and Shafiul Islam, M. (2020). "Aquilaria crassna (Agarwood): Study of pharmacological activity and medical benefits," Open Access Journal of Pharmaceutical Research 4(2). DOI: 10.23880/oajpr-16000200

Ariff, Z. M., Rahim, N. A. A., and Low, L.C. (2008). "Effect of compound formulation on the production and properties of epoxidised natural rubber (ENR-25) foams," in: Proceedings of the Polymer Processing Society $24^{\text {th }}$ Annual Meeting, Salerno, Italy,

ASTM D1056 (2014). "Standard specification for flexible cellular materials-Sponge or expanded rubber," ASTM International, West Conshohocken, PA, USA.

BOI (2018). "Thailand: World's top supplier of natural rubber," (https://www.boi.go.th/upload/content/Rubber_Industry2018_5bb33471b8292.pdf), Thailand Board of Investment (BOI), Accessed 26 May 2020.

Cao, X., Lee, L. J., Widya, T., and Macosko, C. (2005). "Polyurethane/clay nanocomposites foams: Processing, structure and properties," Polymer 46(3), 775783. DOI: $10.1016 /$ j.polymer.2004.11.028

Dahham, S. S., Tabana, Y. M., Sandai, D., Ahmed, M. A., and Majid, A. M. S. A. (2016). "In vitro anti-cancer and anti-angiogenic activity of essential oils extracts from agarwood (Aquilaria crassna)," Medicinal \& Aromatic Plants 5(4). DOI: $10.4172 / 2167-0412.1000256$

Eiadthong, W. (2007). "Aquilaria rugosa (Thymelaeaceae): A new record for Thailand," The Thailand Natural History Museum Journal 2(1), 63-66. 
Industrial product standards Act (1976). "Thai industrial product standards (TIS 1732519): Natural rubber latex foams," Thai industrial standards institute, Ministry of Industry, Bangkok, Thailand.

Ismail, H., Nasaruddin, M. N., and Ishiaku, U. S. (1999). "White rice husk ash filled natural rubber compounds: The effect of multifunctional additive and silane coupling agents." Polymer Testing 18(4), 287-298. DOI: 10.1016/S0142-9418(98)00030-0

Jamroenprucksa, M. (2007). "Domestication of agarwood in Trat province," in: Proceedings of the $8^{\text {th }}$ of Silvicultural Seminar: Silvicultural Technology for the Eradication of Poverty, Bangkok, Thailand, pp. 180-189.

Jindawech, W., Laemsak, N., and Hengniran, P. (2015). "Agarwood oil production in Chanthaburi Province," Thai Journal of Forestry 34(1), 112-121.

Kasikranan, S. (2012). "Para rubber (Hevea brasiliensis) cultivation, production and trading of Para rubber raw materials in the Greater Mekong Sub-region (GMS)," Journal of Science and Technology MSU 31(5), 681-688.

Kudori, S. N. I., Ismail, H., and Shuib, R. K. (2019). "Kenaf core and bast loading vs. properties of natural rubber latex foam (NRLF)," BioResources 14(1), 1765-1780. DOI: 10.15376/biores.14.1.1765-1780

Mokhtari Motameni Shirvan, M., Famili, M. H. N., and Golbang, A. (2016). “A review on the application of nucleation theories in thermoplastic foams," Plastic and Polymer Technology 4, 11-32. DOI: 10.14355/papt.2016.04.002

Moungsrimuangdee, B., Sangwanit, U., and Jamroenprucksa, M. (2016). "Results of agarwood inducement in the stems of Aquilaria crassna Pierre ex Lecomte growing in the farmers' plantations, Trat Province," Thai Journal of Forestry 35(1), 34-44.

Muniandy, K., Ismail, H., and Othman, N. (2012). "Effects of partial replacement of rattan powder by commercial fillers on the properties of natural rubber composites," BioResources 7(4), 4640-4657. DOI: 10.15376/biores.7.4.4640-4657

Najib, N. N., Ariff, Z. M., Manan, N. A., Bakar, A. A., and Sipaut, C. S. (2009). "Effect of blowing agent concentration on cell morphology and impact properties of natural rubber foam," Journal of Physical Science 20(1), 13-25.

Ramasamy, S., Ismail, H., and Munusamy, Y. (2012). "Tensile and morphological properties of rice husk powder filled natural rubber latex foam," Polymer-Plastics Technology and Engineering 51(15), 1524-1529. DOI: 10.1080/03602559.2012.715361

Ramasamy, S., Ismail, H., and Munusamy, Y. (2013a). "Effect of rice husk powder on compression behavior and thermal stability of natural rubber latex foam," BioResources 8(3), 4258-4269. DOI: 10.15376/biores.8.3.4258-4269

Ramasamy, S., Ismail, H., and Munusamy, Y. (2013b). "Preparation and characterization of rice husk powder incorporated natural rubber latex foam," Advanced Materials Research 626, 523-529. DOI: 10.4028/www.scientific.net/AMR.626.523

Sauki, A., Shahid, M. H. M., Hamid, K. H. K., Azizi, A., Jamaludin, S. K., Mohd, T. A. T., and Alias, N. H. (2013). "Utilization of agarwood distillation waste in oilwell cement and its effect on free water and porosity," International Journal of Science and Engineering 5(2), 61-65. DOI: 10.12777/ijse.5.2.61-65

Shahruddin, M. Z., and Jasni, M. I. S. (2014). "Polymeric composite membrane for $\mathrm{CO}_{2} / \mathrm{CH}_{4}$ separation," in: International Conference on Global Sustainability and Chemical Engineering (ICGSE) 2014, M. Hashim (ed.), Springer, Singapore, pp. 167-176. DOI:10.1007/978-981-287-505-1_20

Siripatanadilox, S. (2007). "Species and trade of agarwood," Journal of Forest 
Management 1, 19-31.

Tangboriboon, N., Samattai, S., Kamonsawas, J., and Sirivat, A. (2015). "Processing of kaolinite and alumina loaded in natural rubber composite foams," Materials and Manufacturing Processes 30(5), 595-604. DOI: 10.1080/10426914.2014.994768

Vahidifar, A., Nouri Khorasani, S., Park, C. B., Khonakdar, H. A., Reuter, U., Naguib, H. E., and Esmizadeh, E. (2016). "Towards the development of uniform closed cell nanocomposite foams using natural rubber containing pristine and organo-modified nanoclays," RSC Advances 6(59), 53981-53990. DOI: 10.1039/C6RA08168A

Wetwitayaklung, P., Thavanapong, N., and Charoenteeraboon, J. (2009). "Chemical constituents and antimicrobial activity of essential oil and extracts of heartwood of Aquilaria crassna obtained from water distillation and supercritical fluid carbon dioxide extraction," Silpakorn University Science and Technology Journal 3(1), 25 33. DOI: $10.14456 /$ sustj.2009.3

Yip, E., and Cacioli, P. (2002). "The manufacture of gloves from natural rubber latex," The Journal of Allergy and Clinical Immunology 110(2), S3-S14. DOI: 10.1067/mai.2002.124499

Yoswathana, N., Eshiaghi, M. N., and Jaturapornpanich, K. (2012). "Enhancement of essential oil from agarwood by subcritical water extraction and pretreatments on hydrodistillation," International Journal of Chemical and Molecular Engineering 6(5), 453-459. DOI: 10.5281/zenodo.1060381

Zakaria, Z., Ariff, Z. M., Hwa, T. L., and Sipaut, C. S. (2007). "Effect of foaming temperature on morphology and compressive properties of ethylene propylene diena monomer rubber (EPDM) foam," Malaysian Polymer Journal 2(2), 22-30.

Article submitted: July 24, 2020; Peer review completed: October 31, 2020; Revised version received and accepted: November 3, 2020; Published: November 12, 2020. DOI: $10.15376 /$ biores.16.1.176-189 